\title{
Criação de Livro llustrado a partir de Monstros do Imaginário Medieval
}

\section{Daniela T. Koyama (IC)}

\section{Resumo}

Este projeto resume-se a um estudo teórico-prático sobre monstros presentes em manuscritos medievais. Nos propusemos a elaborar um livro ilustrado a partir das traduções coletadas de descrições e relatos a respeito desses seres fantásticos.

Palavras Chave: monstros, medieval, fantástico, livro-ilustrado.

\section{Introdução}

O bestiário é um gênero da literatura medieval que reúne diversas descrições e histórias de animais, criaturas fantásticas, reais e imaginárias, que estavam associadas ao simbolismo cristão ou a lições moralizantes. Foram muito populares na Inglaterra entre os séculos XII e XIII e espalharam-se por toda a Europa, perdurando até o século XVI. A existência desse tipo de material pode ser conseqüência da constante indagação de um imaginário medieval sedento por descobertas a respeito do universo que 0 cercava. Quais seres e entidades metamórficas, viveriam nos confins da Terra, ou melhor, daquela Terra onde o homem europeu e feudalizado ainda não havia chegado? O projeto surge de um desdobramento dessas questões, dum desejo de reunir o que há de mais fantástico nesses livros e reapresentá-lo atualmente.

\section{Resultados e Discussão}

Usamos como base para as traduções o livro Pride and Prodigies: Studies in the Monsters of the Beowulf-manuscript. Outra referência usada nesta caçada por descrições foram as gravuras de Giovanni Battista de' Cavalieri, que além de apresentar o texto descritivo também possuía ilustrações das criaturas. O Monstrorum Historia de Ulisse Aldrovandi tem cunho naturalista, ou seja, aborda questões mais biológicas, quase cientificistas, por assim dizer. Essas ilustrações detalhadas nos auxiliaram a vislumbrar outros aspectos de seres monstruosos, como por exemplo, métodos de designação dados a eles.

A partir das questões técnicas levantadas pelos materiais utilizados, demos início à prática. Cuidamos para que os detalhes de cada página do livrinho seguissem o modelo de uma produção medieval até mesmo na questão artesanal, no debruçar minucioso de um iluminador sobre cada ilustração. Prezando tais características, buscamos criar padrões que dialogassem com a figura central da página e que ao mesmo tempo encantasse o leitor com seus inúmeros e minúsculos eventos individuais.

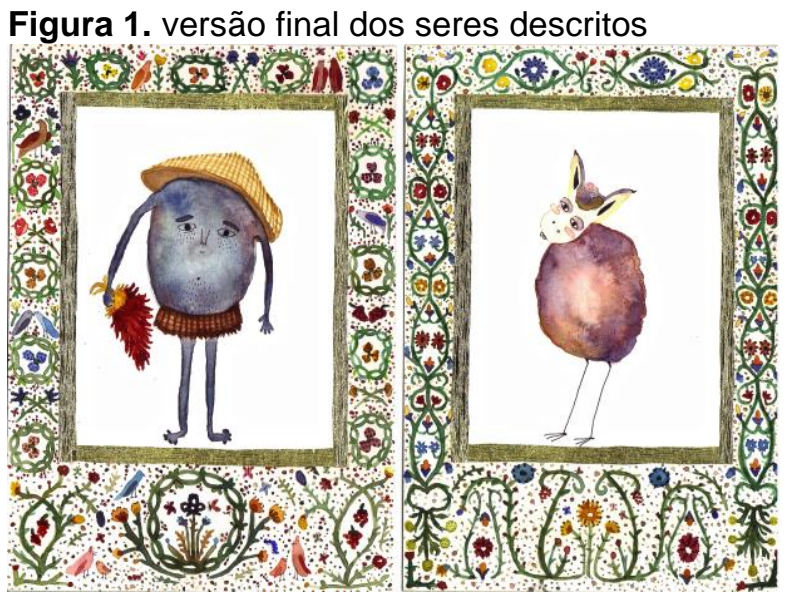

\section{Conclusões}

O projeto teve como intenção reafirmar o valor histórico e imagético desses manuscritos medievais, reapresentando-os numa versão contemporânea e personalizada. Buscamos nas mais diversas fontes relatos e descrições de seres fantásticos que nos serviram de base para criação de um livro ilustrado. Portanto, entrelaçamos produção prática e aspectos teóricos, como tradução e estudo histórico.

\section{Agradecimentos}

Ao Programa Institucional de Bolsas de Iniciação Científica - PIBIC; Luise Weiss; Tuneu; Sérgio Niculitcheff e amigos que contribuíram com sugestões e soluções para a pesquisa.

ALDROVANDI, Ulisse. Monstrorum historia. Prefácio de Jean Céard. Paris; Turim: Les Belles Lettres; Nino Aragno, 2002.

ORCHARD, Andy. Pride and Prodigies: Studies in the Monsters of the Beowulf-manuscript. Toronto:Univ. of Toronto Press, 1995.

BROWN, Michelle. Understanding Illumintated Manuscripts: A Guide to Technical Terms. Malibu, British Library, 2007. 